\title{
The Impact of Inflation Prospects on Investments of Industrial Companies (Jordan' Case)
}

\author{
${ }^{1}$ ABDUL AZIZ FARID SAYMEH, ${ }^{2}$ MARWAN MOHAMMAD ABU ORABI, \\ ${ }^{3}$ ABDULLAH A.S. ALSHOURAH \\ ${ }^{1}$ Middle East University, Amman, JORDAN \\ ${ }^{2}$ World Islamic Science University, Amman, JORDAN \\ ${ }^{3}$ World Islamic Science University, Amman, JORDAN
}

\begin{abstract}
This paper aimed to evaluate the impact of inflation prospects on investments of Industrial Companies in Jordan. The main objective is to elaborate the most relevant and feasible techniques to improve the prospects for developing the invests in the industrial sector. In the introduction part, inflation prospects and selected methods of analysis via available information resources were defined. It is well known that inflation is a prominent economic phenomenon in the modern world. The financial inflation is the prime objective of present study because it is primarily concerned with the investment process, especially to consider that inflation almost affects both the foreign and domestic direct investments by almost equal rates. The topic of industrial development is highly concerned with process of investment in Jordan. This research deals with the inflation effect on investment outcomes of most industrial companies in Jordan. This study will contribute to enrich the existing literature with financial structure and investment decisions via monetary inflation represented by capital, commodity and imports within the set of industrial companies. The study tool is a questionnaire that collected the needed data aiming to elaborate the preset conclusions of this research. Pearson correlation testing program was implemented to measure the relation between inflation and investment procedures. Overall outcomes revealed that the lowest coefficient observed between imports inflation. and all other variables were reversed, most increases in imports inflation were almost stabilized by the decrease of the other variables. While all other correlation values were positive.
\end{abstract}

Keywords: inflation, monetary inflation, investment, investment decisions.

Received: September 14, 2020. Revised: May 11, 2021. Accepted: May 14, 2021. Published: May 21, 2021.

\section{Introduction}

\section{1-1- Preface}

It worth to indicate that inflation sets the most prominent economic phenomenon and manifestation in the modern world, where prices are increasing by increasing levels, which encouraged the researchers of economic studies to pursue the causes of this increase via their studies, so the risk of inflation has been loomed after the past fifty years of crises in the global economy caused by inflation and its outcomes. Thus, inflation usually affects all economic principles and finance, including the economic and financial theories that crystallize according to their effects. So, high inflation and devaluation usually contribute to serious 
repercussions on economies, that might affect both long and short periodic investment procedures of most institutions. However, as most investment institutions intend to guarantee and maximize profitability, so in case of inflation, they are threatened with bankruptcy and lower interest in their outcomes [1]. It is favorable to add that there is much required to evaluate the effect of inflation, as it decreases the currency purchasing power when taking investment decisions by the Jordanian industrial companies [2].

The current conditions in our time and the accompanying rise in prices and taking into account the factor of inflation, as this factor leads to many bit faults that might face individuals or companies, especially private consumers as well as industrial companies, therefore, the decisions of these companies to invest are the prime factors affecting their profitability, continuity and prosperity in the concerned markets. Hence, this study showed the inflation impact on all kinds of commodity, capital and incoming inflation for industrial companies in Jordan. Some relevant studies can be found in San Jay Kumar in the article titled: Impact of Inflation on Investment Decisions, With Calculations [36], and a research by U.S. Bank Asset Management Group, July 2020 titled: "Investing when inflation is on the rise, [37].

\section{1-2-The study importance:}

This study deals with the effect of currency inflation on trading decisions of Jordanian industrial companies. The study is aimed to advocate and enrich the current understanding of the conceptual framework of investment plans via monetary inflation which are figured out by capital, goods, real estates, and incoming inflation in to the Jordanian industrial companies. As per the researcher's knowledge, this subject had not been adequately dealt with by previous researches, so this research will establish a base for future researches.

\section{Literature:}

\section{2-1-Inflation}

\section{2-1-1-What is inflation:}

Inflation had long been a central and controversial issue in modern economy. Inflation is the decline of the purchasing power of any currency over time periods. The quantitative estimate of the rate at which the decline in purchasing power occurs can be reflected in the increase of an average price level of a basket of selected goods and services in an economy over some period of time. The increase in the general level of prices, often expressed a percentage means that a unit of currency effectively buys less than it did in prior periods.

2-1-2-Inflation Concept: It is a prime and highly common economic concept, as there is no agreement between the competent authorities that refers to its definition accurately. It worth to indicate that the concept of inflation is counted via many cases and phenomena as not dependent on other factors, this independence has raised some confusion in elaborating this principle.

Inflation is defined as the excessive increase in most prices, i.e., the increase in the cash available without the increase of goods and services volumes [3], while it can be seen as the constant rise in common goods price levels [4]. Also, it is defined as the high-income cash level or the monetary income sectors numbingly wages and profits [5]. In general, in case of currency devaluation, usually prices will rise. While it might be defined as the continually upward prices, leading to high demand rather than supply [6]. Inflation concept includes the following sub concepts:

- Inflation is the rate that the value of any currency is dropping and consequently the general level of price levels for goods and services is increasing.

- Inflation may be classified into three kinds: Demand-Pull, Cost-Push, and the Built-In inflation.

- The main inflation indexes used are the Consumer Price Index and the Wholesale Price Index.

- -Inflation can be positively or negatively considered depending on the financial expert's viewpoint and rate of change significance.

- As with tangible assets, such as property, stocks, and commodities, owners may would like to see some inflation as that raises the value of their assets.

- People who hold cash will not like inflation, as inflation erodes the value of their money.

- An optimum level of inflation is sometimes required to promote spending levels into a certain extent rather than saving, thereby will nurture economic growth. 
- Moreover, the researchers had considered inflation as the state of the general increase in prices that would lead to a wide gap between the goods volume and Income levels available for expenditure [30].

\section{2-1-3- Understanding Inflation}

As it is mainly easy to measure the price changes of consumer basket products over time, still the human needs would extend a lot beyond the typical products. Individuals mainly need a big and diversified set of products as well as a set of services for living a comfortable and healthy life. Consumers usually include commodities such as food grains, metal and fuel, utilities like electricity and transportation, and other services like healthcare, entertainment, and labor. Inflation aims to evaluate the overall impact of price changes for a diversified set of products and services, and mainly allow for a single value representation of the increase in the price level of goods and services in an economy over certain time periods.

However, as currency usually loses value, prices rise continually and turn consumers to buy less goods and services. This financial loss of purchasing power affects the general cost of living for the common public which ultimately leads to a deceleration in economic growth. The general consequential view among most economists is that the sustained inflation takes place almost when a nation's money supply growth outpaces the national economic growth [32].

\section{2-1-4- Inflation Characteristics:}

As per this criterion, inflation definition is related to the properties of the impacts of high prices. This increase might not be always regular [7], while some authors believe that inflation is the continual movement of high price levels in the markets, so, inflation is the upward movement of public and private price levels accompanied by a permanent decline in the purchasing effect which meets one unit of commodity [8]. Inflation can also be viewed as of this theory as the irregular rise in prices or the general movements of prices above the currency cash element as the prime driving force.

\section{2-1-5-: Types of inflation}

The high multiplicity in the inflation principle which had led to the existence of multiple types of it. Some of these types have common relations and characteristics based on the different assumptions that state out the inflation concept to be an economic principle. Therefore, these types can be mentioned in many class levels, the type which was presented by the researchers Brigo \& Mercurio, is the following: [12].

1- Commodity inflation: inflation of goods, which affects super level profits in the industries of these commodities. This kind of inflation occurs in commodity production as it reveals the increase in consumption expenditure rate than savings [10].

2- Capital inflation: it takes place in the investment sector, as it reflects the increase in the value of investment goods on their production expense, and their outcome on the outbreak of these inflationary trends, as well as the immediate substantial profits achieved in the sectors of consumption, saving, and investment [11]. Also, it is clear that inflation occurs in the area of investment goods which leads to high profits in the commodity production industries through investments [12].

3- Imported inflation: This type deals with the rise of prices due to the imported inflation through imports, and thus, the country's exports already suffer from this inflation, so this inflation is transmitted through the goods and services of foreign countries [13], this kind of inflation is tied with the foreign trade transactions, and in turn it leads that workers will demand that their wages and monthly salaries be increased and this increment becomes an effective demand [14].

\section{2-2: Investment Concept}

This is among the highest influential economic concepts in organizations of their different operating activities. It is spelled out as the pursuit of a set of benefits expected to be acquired within a time period via the most effective utilization of the available tangible and financial assets. [15]. The economy and the science of finance have many definitions of the investment concept. It is possible to refer to the definition of investment as the acquisition of physical assets through the use of funds and their 
utilization in contributing to productive processes [10].

In terms of economic terms, investment is the exploitation of the funds in order to earn future returns to achieve a set of benefits by employing capital in studied projects whether services, production, or renewing and modernizing of existing projects [1][31].

The concept of investment macroeconomic is known as the efficient allocation of available material and moral economic resources by the following ideas [16]:

- The investment is to purchase a set of financial commodity assets named: bonds and stocks.

- Buying assets or capital goods such as machines, which are seen as the origin and goods production tools.

The concept of investment is the acquisition of physical and financial assets. This investment becomes meaningful via the use of capital different financial gadgets [17], while it can be proposed as the postponement of consumption of financial tools for later time periods and then channeling these funds to investment, development, employment and not to hoarding and saving [18]. In terms of financial principles, investment principle can be revealed as the productive employment of financial properties via channeling savings towards uses that lead to the creation of goods or services aimed at satisfying the needs of the society members and via achieving their prosperity [19]. Thus, investment in the present system is the rational investment of practical financial assets to realize meaningful outcomes by all forms of cash flows in the future in return for certain compensations and any risks arising from uncertainties [20].

\section{2-2-1-The Objectives and Outcomes of Investment}

Main prime objective of trading for all participants to generate future profits in return for risk-taking in order to build wealth [2]. [18], also, the outcome of trading is accomplished by applying financial and economic methods aimed at wealth formation and development after the sacrifice of all property forms in the expectations of success.

Hence, the researchers think that the role of investment and its objectives are repatriated in the principle that investors must strive to maintain their assets through their experiences to perform in different investment areas in a bid preserve the value of their resources (wealth) via time periods by using multi factors to affect these trade practices. Some researchers believe that investment is a process of sacrificing certain financial values aiming to obtain the following potential outcomes:

1- To sacrifice money, cash and other assets.

2- The ability of obtaining future returns.

3- Expect greater cash. [20].

\section{2-2-2-Investment decisions}

They are among the most difficult decisions facing the investors of all the work sectors, because they relate to the future of any investment of funds that are not expected to yield in the future. The difficulty of such decisions is that they depend totally on the prediction, the outcomes, activities, and plans of the organization [21]. Investment plans usually depend on the existence of true information and work conditions for effective application, which is one of the most important bases of taking sound investment decisions. Good and realistic information comes from realistic and perfect data [2]. That investment decisions are the most important effect on the forward time periods of the enterprises [29].

\section{2-2-3-Types of Investment Decisions}

There are many types of investment decisions taken by institutions, they vary depending on the type and duration of the investment case. Investment decisions are the essence of the foundation in the work of organizations, enterprises and economic units in all their forms and types, it is composed of:

1-Direct investment decisions: Decisions in companies via the possession of real components, machinery, imported goods, real estate and others. In this investment, it means that the possession of assets that have economic value and having additional economic benefits such as produced goods [22], and the companies' role in taking decisions directly to get the maximum profitability via risk cases and under the effect of a set of factors such as the phenomenon of inflation. The realistic principle of such objectives is to generate wealth as a prime outcome, which is referred as the term "direct investment" or "project". So, prospective investment decisions consist of all areas of direct investment, whether locally or externally [11][28]. 
2-Indirect investment decisions: It is that the establishments in their possession of assets in part can be intangible and non-real represented in shares, bonds, certificates of deposit, and others [23].

\section{Previous Researches:}

3-1- Geoffrey T. (1996), is titled: The Impact of Inflation on Capital Budgeting and Working Capital [21]

Present paper had elaborated the effect of price inflations on the processes of financial budgeting. It cleared that it is logical to forecast the capital cost with the price increase rate on time period's basis, so this increase forms a multiplier function. Also, this paper had revealed that the process of capital budgeting was not even as to inflation. A part of the crucial importance was the percentage of net working capital as a component of the financial requirement, there is a progressive proportion between net working capital and inflation on capital spending.

3-2-: Ciżkowicz P. and Rzońca A., (2013), Titled: Does Inflation Harm Corporate Investment? Empirical Evidence from OECD Countries [13]

Researchers had examined the correlation among the investment and inflation of institutions. Researchers had used a 21 members study sample for The Economic Co-operation and Development Organization for 1960-2005 period. They found strong and sharp opposite relationship of the variables and have suggested that there was no direct relation between inflation and return outcomes depicted from the non-straight relation of inflation and investment. For this, the central bank employs the inverse attitude in low time periods via lengthening the economic recovery period.

\section{3-3- Garoufalis K., 2017, Titled: Investment Decisions and Inflation [20]:}

This research investigates how trades evaluations would give exact emphasis upon inflation. Investment usually considers that cash returns are always followed by cash benefits as well as price evolutions would inflate the current prices by amounts that would get bigger by time. It tends that the ways of tackling inflation in projects evaluations would represent a set of causes that would deplete investment. It tends to be clear that the impact from the disregard of price inflation is likely to magnify the expected inflation rates. However, the process of price hugeness in the evaluation process would act as a mandatory allowance called risk.

3-4-: Abu Asab N. \& Al-Tarawneh A.,2018, Titled: The Impact of Inflation on Investment: The Multi-Linear Relationship and Inflation Boom in Jordan [2].

Subject study had highlighted the nonlinear relation of inflation and trade in the major productive Jordanian establishments. Applying the outset pattern for 1980-2016 period, the outcomes had revealed that investment had receded in negligible rates by inflation when inflation rates were at levels below $10 \%$. This proposes that inflation rates should be kept below $10 \%$ to continue in order to improve investment standards.

3-5- Pavel Taraba, 2019, titled: Project management methods in conditions of business companies in the Czech Republic [28] This study aimed to evaluate the implementation of project management aspects in some business companies in the Republic of Czech. With the use of a questionnaire survey, the level of application of project management methods in conditions of business companies in the Czech Republic was evaluated. The questionnaire survey was conducted in four stages; Two research questions were formulated. 1) Are the methods of project management applied in most of the surveyed companies at a "very high" or at a "high" level? 2) Is it possible to observe a growing trend in the application of project management methods in the period 2015-2018 in the surveyed companies? Based on a comparison of the results of the individual analyses, it is possible to describe the development of the application of the project management methods over the past four years.

3-6- Xiaohua Duan, 2019, titled: Systematic Risk Measurement Based on CoVaR Model [36]

In this research, the author had selected three insurance companies listed in China as the research condition. He used the model and quantile regression model combined to conduct the empirical analysis in a bid to measure the spillover impact of systemic risk in these insurance companies. The analysis outcomes showed that the risk spillover value of CPIC 
(China Pacific Insurance Company) was the largest, followed by China Life, and Ping'an Insurance Company of China was the last. Finally, the researcher had put forward the countermeasures and suggestions to prevent the systemic risk of insurance industry by combining the results of the empirical analysis.

\section{Study Problem, Model, and hypotheses \\ 4-1-Study problem}

The researchers were inclined to document in detail the nature of the empirical linkages between inflation and the industrial system. In order to do so, so the employed the timeaveraged data over periods of several decades from a large number of industrial companies listed on Jordan's ASE, and then were exploring the cross-sectional relationship between inflation, and an array of indicators of financial market conditions. Th do so we had to formulate a set of questions as follows:

The general question was: Was There any statistical effects at $(\alpha=0.05)$ significant level of inflation (capital inflation, commodity inflation, imported inflation) on investment judges (direct investment decisions, indirect investment decisions) of industrial companies listed on ASE. This main question was subdivided inti the following sub questions:

Was there any statistical effect at $(\alpha=0.05)$ significance level of capital inflation on investment judges (direct investment decisions, indirect investment decisions) of industrial companies in Jordan?

Was there any statistical effect at $(\alpha=0.05)$ significance level of commodity inflation on the investment judges (direct investment decisions, indirect investment decisions) of industrial companies in Jordan?

Was There any statistical effect at $(\alpha=0.05)$ significance level of imported inflation on investment judges (direct investment decisions, indirect investment decisions) of industrial companies in Jordan?

\section{4-2-Study Hypotheses:}

As per the set of questions, following are the corresponding hypotheses:

IV-2-1: - The prime hypothesis (H-O): There was no statistical effect at $(\alpha=0.05)$ significant level of inflation (capital inflation, commodity inflation, imported inflation) on investment judges (direct investment decisions, indirect investment decisions) of industrial companies listed on ASE.

(H-O) is subdivided into a set of sub-hypotheses:

(H-O-1)-: There was no statistical effect at $(\alpha=$ $0.05)$ significance level of capital inflation on investment judges (direct investment decisions, indirect investment decisions) of industrial companies in Jordan.

(H-O-2)-: There was no statistical effect at $(\alpha=$ 0.05) significance level of commodity inflation on the investment judges (direct investment decisions, indirect investment decisions) of industrial companies in Jordan.

(H-O-3)-: There is no statistical effect at $(\alpha=$ $0.05)$ significance level of imported inflation on investment judges (direct investment decisions, indirect investment decisions) of industrial companies in Jordan.

\section{4-3-Study Model:}

As per the study problem and aforementioned literature, and a set of past studies, the researchers were able to form the following study model. The researchers had formulated the study pattern to close the gap existed in the previous studies. 
Figure (1-1): Research Pattern:

\begin{tabular}{|l|l|}
\hline \multicolumn{1}{|c|}{ Independent-Variable } & \multicolumn{1}{c|}{ Dependent Variable } \\
\hline Monetary Inflation: & Investment Decisions: \\
-Direct Investment Decisions & -Capital Inflation \\
-Indirect Investment Decisions & - Commodity inflation \\
& - imported inflation \\
\hline
\end{tabular}

To illustrate the study model, the following table (1.1) was created:

\begin{tabular}{|c|c|c|c|}
\hline Variables & Dimensions & N0. of Questions & References \\
\hline $\begin{array}{l}\text { Independent Variable } \\
\text { Inflation }\end{array}$ & Capital Inflation & $13-18$ & Ireland, 2009 \\
\hline $\begin{array}{l}\text { Independent Variable } \\
\text { Inflation }\end{array}$ & Commodity inflation & $7-12$ & Yassin-2005 \\
\hline $\begin{array}{l}\text { Independent Variable } \\
\text { Inflation }\end{array}$ & Imported inflation & $1-6$ & Raj, et al., 2008 \\
\hline $\begin{array}{l}\text { Dependent Variable } \\
\text { Investment Decisions }\end{array}$ & Capital Inflation & $19-24$ & Duflo \& Saez, 2002 \\
\hline $\begin{array}{c}\text { Dependent Variable } \\
\text { Investment Decisions }\end{array}$ & $\begin{array}{l}\text { Indirect Investment } \\
\text { Decisions }\end{array}$ & $25-30$ & Hou, et al., 2015 \\
\hline
\end{tabular}

Source: Table is prepared by the researcher as per presented references.

\section{Study Methods and procedures}

\section{5-1- Study methods:}

Descriptive statistics: this kind of analysis give an aid to the researchers to simplify large sets of data in a sensible way. Each descriptive statistic briefs data into a simple summary. Descriptive statistics helps facilitate data visualization. It allows for data to be presented in a meaningful and understandable way, which in turn, allows for a simplified interpretation of the data set in question [33].

The prime outcome of this study was to elaborate the effect of monetary inflation on trading determinations: A study sample is the list of Amman Stock Exchange industrial companies. To attain this goal, a descriptive program was conducted. The theoretical approach was conducted for the study variables. The analytical approach was based on the correlation and regression of the study variables which were extracted from the feedback responses on the statements of the questionnaire whose statements covered all the study variables.
Research population is composed of (257) employees in large (4) Jordanian industrial companies randomly selected, and a set of (50) members was randomly picked up.

\section{5-2- POPULATION AND SAMPLE:}


Table -2-: The questionnaires distributed and returned back and were valid for the analysis:

\begin{tabular}{|c|c|c|c|}
\hline Sample of Study & $\begin{array}{c}\text { Questionnaires } \\
\text { distributed }\end{array}$ & Retrieved questionnaires & Valid questionnaires \\
\hline Employees numbers & 50 & 45 & 40 \\
\hline
\end{tabular}

Source: Questionnaires were prepared by the study team.

\section{5-3-Study tools:}

In a bid to collect the data required for hypotheses study, the set of questions was formulated as follows:

- Independent variables: Monetary inflation evaluated using three parameters

- First Set: imported inflation, (1-6). paragraphs.

- Second Set: commodity inflation and guarantees (7-12) paragraphs.

- Third Set: capital inflation, (13-18) paragraphs.

- Dependent variables: investment resolutions

- First dimension: direct resolutions (19-24) paragraphs.

- Second dimension: Indirect resolution: (2530) paragraphs.

The measure system of the responses is based on: Likert Scale, which is among the most widely used and easy to understand, and is as follows: (1-5) where (1) not full agreement (5) full agreement. The importance level for the locality of the answers counted was determined as per the presented ratios:

$(5-1) / 3=1.33$ and then distributed as follows: 1-2.33 is Poor, $2.34-3.66$ is Average, $3.67-5$ is High.

\section{5-4- Tools of reliability and stability tests}

To ascertain the veracity of the questionnaire was given to a group of specialists who were guided by their decisions on the ability of the paragraphs to measure variables along to the purity and integrity of the wording of the paragraphs.

To ascertain the uniformity of the responses sample unit feedbacks, the Cronbach Alpha value was calculated. The overall ratio of the conformity of the feedbacks to the paragraphs of the questions set was $86.4 \%$, which is above the minimum acceptable rate. 
Table (2): - Stability coefficient of research variables (Alpha Cronbach Scale):

\begin{tabular}{|c|c|c|c|c|c|c|}
\hline Variables & $\begin{array}{c}\text { Imported } \\
\text { inflation }\end{array}$ & $\begin{array}{c}\text { Commodity } \\
\text { inflation }\end{array}$ & $\begin{array}{c}\text { Capital } \\
\text { Inflation }\end{array}$ & $\begin{array}{c}\text { Direct } \\
\text { Investment } \\
\text { Decisions }\end{array}$ & $\begin{array}{c}\text { Indirect } \\
\text { Investment } \\
\text { Decisions }\end{array}$ & $\begin{array}{c}\text { General } \\
\text { stability rate }\end{array}$ \\
\hline $\begin{array}{c}\text { Alpha } \\
\text { Cronbach }\end{array}$ & 0.77 & 0.89 & 0.613 & 0.865 & 0.821 & 0.864 \\
\hline
\end{tabular}

\section{6- Results and Conclusions}

6-1- Results:
1-: To identify the correlation factors between the research variables, the Pearson's correlation point was estimated between all study variables and it is reflected in the following table.

Table (3) Pearson correlation coefficient between the study variables

\begin{tabular}{|c|c|c|c|c|c|c|}
\hline & & $\begin{array}{l}\text { Imported } \\
\text { inflation }\end{array}$ & $\begin{array}{c}\text { Commodity } \\
\text { inflation }\end{array}$ & $\begin{array}{l}\text { Capital } \\
\text { Inflation }\end{array}$ & $\begin{array}{c}\text { Direct } \\
\text { Investment } \\
\text { Decisions }\end{array}$ & $\begin{array}{c}\text { Indirect } \\
\text { Investment } \\
\text { Decisions }\end{array}$ \\
\hline $\begin{array}{l}\text { Imported } \\
\text { inflation }\end{array}$ & $\begin{array}{l}\text { Pearson } \\
\text { Correlation } \\
\text { Sig. (2-tailed) }\end{array}$ & 1 & & & & \\
\hline $\begin{array}{l}\text { Commodity } \\
\text { inflation }\end{array}$ & $\begin{array}{l}\text { Pearson } \\
\text { Correlation } \\
\text { Sig. (2-tailed) }\end{array}$ & $\begin{array}{l}-.446 \\
.004\end{array}$ & 1 & & & \\
\hline $\begin{array}{l}\text { Capital } \\
\text { Inflation }\end{array}$ & $\begin{array}{l}\text { Pearson } \\
\text { Correlation } \\
\text { Sig. (2-tailed) }\end{array}$ & $\begin{array}{l}-.233 \\
.147\end{array}$ & $\begin{array}{l}.406^{* *} \\
.009\end{array}$ & 1 & & \\
\hline $\begin{array}{l}\text { Direct } \\
\text { Investment } \\
\text { Decisions }\end{array}$ & $\begin{array}{l}\text { Pearson } \\
\text { Correlation } \\
\text { Sig. (2-tailed) }\end{array}$ & $\begin{array}{l}-.142 \\
.381\end{array}$ & $\begin{array}{l}.676^{\text {** }} \\
.000\end{array}$ & $\begin{array}{l}.555^{* *} \\
.000\end{array}$ & 1 & \\
\hline $\begin{array}{l}\text { Indirect } \\
\text { Investment } \\
\text { Decisions }\end{array}$ & $\begin{array}{l}\text { Pearson } \\
\text { Correlation } \\
\text { Sig. (2-tailed) }\end{array}$ & $\begin{array}{l}-.120 \\
.460\end{array}$ & $\begin{array}{l}.419^{* *} \\
.007\end{array}$ & $\begin{array}{l}.561^{* *} \\
.000\end{array}$ & $\begin{array}{l}.601^{* *} \\
.000\end{array}$ & 1 \\
\hline
\end{tabular}

The correlation among inflation and the direct trading actions was found in the above table as follows:

- Pearson coefficient (0.676) and with statistical power level (0.00).

- Oppositely, the lowest figure (-0.446), at the statistical significance level (0.004) were observed.

It is worth to conclude that all correlation factors among imported inflation and the rest of the variables were reversed, this indicated that the increase in the imported inflation had been adjusted and recompensated by lowering the local variables.
It is important to conclude that the remaining correlation figures among the variables were positive.

\section{6-2: Testing hypotheses}

The multiple regression test was performed at $(\alpha$ $=0.05)$ statistical significance level, the results were as follows:

1- The main hypothesis, which states: "There is no significant impact at $(\alpha=0.05)$ significance level for monetary inflation by excluding (imported inflation, commodity inflation, capital inflation) on investment decisions for the Industrial Companies listed on ASE. 
Table-4: The main hypothesis regression test results:

\begin{tabular}{|c|c|c|c|c|c|c|c|c|}
\hline \multirow[t]{2}{*}{ Mode } & & \multicolumn{2}{|c|}{ Unstandardized Coefficients } & \multirow{2}{*}{$\begin{array}{l}\text { Standardized } \\
\text { Coefficients } \\
\text { Beta }\end{array}$} & \multirow[t]{2}{*}{$\mathrm{t}$} & \multirow[t]{2}{*}{ Sig. } & \multirow[t]{2}{*}{$\mathrm{f}$} & \multirow[t]{2}{*}{ Sig } \\
\hline & & $\mathrm{B}$ & Std. Error & & & & & \\
\hline \multirow[t]{4}{*}{1} & (Constant) & -.273 & .849 & & -.322 & .750 & \multirow{4}{*}{15.764} & \multirow{4}{*}{0.000} \\
\hline & $\begin{array}{l}\text { Imported } \\
\text { inflation }\end{array}$ & .230 & .152 & .186 & 1.519 & .138 & & \\
\hline & Capital inflation & .544 & .142 & .462 & 3.844 & .000 & & \\
\hline & $\begin{array}{l}\text { Commodity } \\
\text { inflation }\end{array}$ & .486 & .126 & .504 & 3.863 & .000 & & \\
\hline & $\begin{array}{ll}R: 0.754 & R^{2}: 0 \\
\end{array}$ & .568 & & & & & & \\
\hline
\end{tabular}

a. Dependent Variable: Investment Decisions

The above table revealed the following:

- Factor (f) had reached (15.764) and

- Statistical power had reached (1000).

This confirmed the positive significant effect of monetary inflation in all its parameters on investment decisions.

Also, from the analysis, it is clear that the coefficient of determination had reached $56.8 \%$, this indicated that imported inflation can explain the variance percentage of the dependent variable of investment decisions.

This means that the main hypothesis (H-O) is rejected, and the alternate hypothesis which states:

There was a significant impact at $(\alpha=0.05)$ significance level for monetary inflation by excluding (imported inflation, commodity inflation, capital inflation) on investment decisions for the Industrial Companies listed on ASE had been accepted.

2- The (H-1)-1 hypothesis states: There was no statistically impact at $(\alpha=0.05)$ significance level for inflation imported on trading decisions by the following parameters (direct and indirect investments) of the industrial companies listed on ASE. The following table gives the needed analysis: 
Table -5-: Test outcomes revealed by the simple regression test of the responses on the sentences related to hypothesis H-1-1.

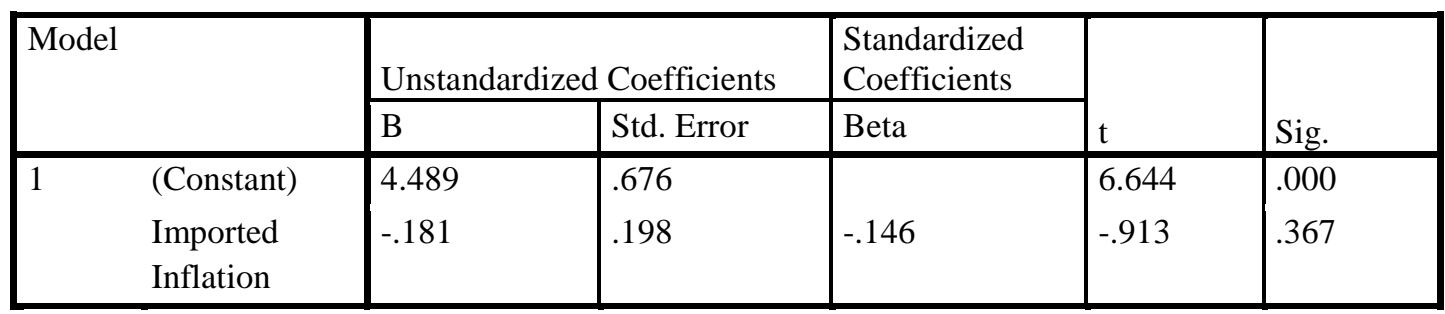

a. Dependent Variable: Investment Decisions

It was evident from the above table that the value of $t$ had reached (-9.13) and the level of statistical significance was $(0.367)$ which means that there was no statistical effect at $(\alpha=0.05)$ significance level, and thus we accept the null hypothesis which stated:

There was no strong positive impact at $(\alpha=$ 0.05) level for imported inflation on the trading decisions by the parameters (direct and indirect investments) of the Industrial Company listed on Jordan's ASE.

3- (H-1)-2 hypothesis: which states that "There was no positive impact at $(\alpha=0.05)$ significance level for inflation of commodities on trading decisions by the parameters (direct and indirect investment) in the Industrial Company listed on ASE. Following tables reveals the results:

Table -6: Test outcomes revealed by the simple regression test of the responses on the sentences related to $\mathbf{H - 1 - 2}$.

\begin{tabular}{|c|c|c|c|c|c|c|}
\hline \multicolumn{2}{|c|}{ Model } & \multicolumn{2}{|c|}{$\begin{array}{c}\text { Unstandardized } \\
\text { Coefficients }\end{array}$} & $\begin{array}{c}\text { Standardized } \\
\text { Coefficients }\end{array}$ & \multirow{2}{*}{ Significance level } \\
\cline { 3 - 5 } \multicolumn{2}{|c|}{} & B & Std. Error & Beta & $\mathrm{t}$ & .000 \\
\hline \multirow{2}{*}{1} & (Constant) & 1.854 & .432 & --- & 4.287 & .000 \\
\cline { 2 - 5 } & $\begin{array}{c}\text { Commodity } \\
\text { inflation }\end{array}$ & .587 & .124 & .609 & 4.733 & \\
\hline
\end{tabular}

The dependent Variable: Investment Decisions

It was evident from the table that $\mathbf{t}$ had reached 4.733 and the significance level was $(\alpha=0.00)$. This was statistically significant which means that the null hypothesis was rejected and the alternative hypothesis which states, there was a significant impact at $(\alpha=0.05)$ significance level for commodity inflation on investment decisions in companies Listed on ASE, was accepted.

4- (H-1-3) hypothesis states: There was no statistical effect at $(\alpha=0.05)$ significance level of the capital inflation on the investment decisions by the parameters (direct and indirect investments) in the Industrial Company listed on ASE. Following table revealed the results. 
Table -7-: Test outcomes revealed by the simple regression test of the responses on the sentences related to $\mathbf{H}-1-3$.

\begin{tabular}{|l|c|c|c|c|c|}
\hline Model & \multicolumn{2}{|c|}{$\begin{array}{c}\text { Unstandardized } \\
\text { Coefficients }\end{array}$} & $\begin{array}{c}\text { Standardized } \\
\text { Coefficients }\end{array}$ & \multirow{2}{*}{} \\
\cline { 2 - 4 } & $\mathrm{B}$ & Std. Error & Beta & $\mathrm{T}$ & Significance \\
\hline 1 (Constant) & 1.589 & .470 & & 3.381 & .002 \\
Capital & .734 & .149 & .623 & 4.914 & .000 \\
Inflation & & & & & \\
\hline
\end{tabular}

a. Variable: Investment Decisions

The above table revealed that $\mathbf{t}$ value had reached (4.914) at $(\alpha=0.000)$ significance level which was considered to be statistically strong at $(\alpha=0.05)$ significance level, so the null hypothesis was rejected and the alternate hypothesis which stated: there was a significant impact at $(\alpha=0.05)$ significance level for capital inflation on investment decisions by the parameters (direct investment, indirect investment) of the industrial companies listed on ASE, was accepted.

\section{Conclusions}

As per the research outcomes, researchers concluded that:

- Investors should be educated about imported inflation and its importance in affecting the inflation levels in the country.

- Imported inflation should be reduced via encouraging the local industry and by obtaining local materials to minimize unexpected imported inflation.

- Future studies are urged to indicate the relationship between imported inflation and other types of inflation resulting from the high cost of imported merchandises from the other countries.

- Research confirmed that commodity inflation has a significant impact on trading decisions of industrial companies Listed on the ASE.

- Research revealed that the impact of inflation on capital spending is proportional to the net working capital.

- It worth to indicate that there was a direct relation between gross profit and inflation rate.

- The research outcomes recommend that inflation rates should be maintained to be low (lower than 10\%) to maintain and keep investment levels.
- An overall conclusion is to generalize the study results for all countries.

\section{References:}

[1] Abele, E., Liebeck, T., \&Worn, A. (2006). Measuring flexibility in investment decisions for manufacturing systems. CIRP Annals-Manufacturing Technology, 55(1), 433-436.

[2] Abu Asab N. \& Al-Tarawneh A.,2018, Titled: The Impact of Inflation on Investment: The Multi-Linear Relationship and Inflation Boom in Jordan

[3] Aharoni, Y. (2015). The foreign investment decision process. In International Business Strategy (pp. 24-34). Routledge

[4] Aivazian, V. A., Ge, Y., \&Qiu, J. (2005). The impact of leverage on firm investment: Canadian evidence. Journal of corporate finance, 11(1-2), 277-291.

[5]Al-Rawi, K. (1999), Investment Concepts of Strategic Analysis, I 1, Baghdad: AlMuthanna Press.

[6]Al-Shabib, D. (2018), Financial and Monetary Markets, I2, Amman: Dar Al-Masirah for Publishing and Distribution.

[7]Bade, R., \&Parkin, M.(2021), Foundations of Economics 8th Edition. amazon.

[8]Bernanke, B. S., Laubach, T., Mishkin, F. S., \& Posen, A. S. (2018). Inflation targeting: lessons from the international experience. Princeton University Press.

[9]Billi, R. M., \& Kahn, G. A. (2008). What is the optimal inflation rate? Economic Review-Federal Reserve Bank of Kansas City, 93(2), 5.

[10]Blaug, M. (1997). Economic theory in retrospect. Cambridge university press.

[11]Brealey, R. A., Myers, S. C., Allen, F., \&Mohanty, P. (2012). Principles of corporate finance. Tata McGraw-Hill Education. 
[12]Brigo, D., \&Mercurio, F. (2007). Interest rate models-theory and practice: with smile, inflation and credit. Springer Science \& Business Media.

[13]Ciżkowicz P. and Rzońca A., (2013), Titled: Does Inflation Harm Corporate Investment? Empirical Evidence from OECD Countries

[14]Dawood, Y. (2001). Critical Theory, I 2, Mosul: Dar Al Kutub for Printing and Publishing.

[15]De Neder land sche Bank NV. BANK ASSET MANAGEMENT GROUP, JULY 2020, TITLED: "INVESTING WHEN INFLATION IS ON THE RISE, INSTITUTIONAL INVESTOR

[16]Evans, C. L. (2012). Monetary Policy in a Low- Inflation Environment: Developing a State- Contingent Price- Level Target. Journal of Money, Credit and Banking, 44(s1), 147-155.

[17]Fase, M. M. G., \&Folkertsma, C. K. (1996). Measuring inflation: an attempt to operationalize Carl Menger's concept of the inner value of money.

[18]Friedman, M. (1960). A program for monetary stability (Vol. 541). New York: Fordham University Press.

[19]Galí, J. (2015). Monetary policy, inflation, and the business cycle: an introduction to the new Keynesian framework and its applications. Princeton University Press.

[20]Garoufalis, K, 2017: Investment Decisions and Inflation, Economics, Business Social Sciences and Education.

[21]Geoffrey T. (1996), THE IMPACT OF INFLATION ON CAPITAL BUDGETING AND WORKING CAPITAL, Journal of Financial and Strategic Decisions Volume 9 Number 1

[22]Gujiani, A. (2011). Inflation, Uncertain Inflation and Monetary Policy, Rafidain Development Journal, 103. 33, 110-129.

[23]Hou, K., Xue, C., \& Zhang, L. (2015). Digesting anomalies: An investment approach. The Review of Financial Studies, 28(3), 650-705.

[24]JASON FERNANDO, 2020, Manufactured Payment, Investopedia.

[25]Mishkin, F. S. (2007). Monetary policy strategy. MIT press.

[26]Nell, K. S. (2004). The structuralist theory of imported inflation: an application to South Africa. Applied Economics, 36(13), 14311444.
[27]Noura Abu Asab \& Alaaeddin Al-Tarawneh, (2018), The Impact of Inflation on Investment: The Non-Linear Nexus and Inflation Threshold in Jordan. Modern Applied Science; Vol. 12, No. 12; 2018

[28]Pavel Taraba, Project management methods in conditions of business companies in the Czech Republic. pp. 46-52, Volume 13, 2019, International Journal of Circuits, Systems and Signal Processing.

[29]San Jay Kumar,2019 in the article titled: Impact of Inflation on Investment Decisions, With Calculations ADVERTISEMENTS, International Journal of Recent Technology and Engineering (IJRTE)

[30] Saunders, A., \& Cornett, M. M. (2003). Financial institutions management: A risk management approach. Irwin/McGraw-Hill. [31] Shukairi, N., Zarkan, S., Aldwikat, F. \& Haddad, (2016). Investment Management, I2, Amman: Dar Al Masirah for Publishing and Distribution.

[32]Tirole, J. (2010). The theory of corporate finance. Princeton University Press.

[33]Turvey, R. (2017). Optimal Pricing and Investment in Electricity Supply: An Esay in Applied Welfare Economics. Routledge.

[34]Vestin, D. (2006). Price-level versus inflation targeting. Journal of Monetary Economics, 53(7), 1361-1376.

[35] William M.K. Trochim,2020, The Research Methods Knowledge Base, Investopedia.

[36] Xiaohua Duan, Systematic Risk Measurement Based on CoVaR Model, pp. 243-250, Volume 13, 2019, International Journal of Circuits, Systems and Signal Processing.

\section{Creative Commons Attribution License 4.0 (Attribution 4.0 International, CC BY 4.0)}

This article is published under the terms of the Creative Commons Attribution License 4.0

https://creativecommons.org/licenses/by/4.0/deed.en_US 